\title{
The Flipping Classroom and its Application in College English Teaching
}

\author{
LIU Yu \\ General Foreign Languages Teaching Department, Baicheng Normal University, Baicheng, 137000, \\ China \\ email: liuyu58825@126.com
}

Keywords: The Flipped Classroom, College English, Teaching Application

\begin{abstract}
Based on the analysis of the definition and development of flipping classroom, this paper will further explore the feasibility of the application of flipping classroom in college English teaching. Then combining with the present situation of college English teaching and the advantages of flipping classroom, this paper puts forward some views on how to make use of flipping classroom to develop English teaching.
\end{abstract}

\section{Introduction}

With the rapid development of information technology, the application field of information technology has been gradually expanded. At present, the educational circles have followed the development of information technology to actively utilize the advantages of information technology to carry out education and teaching reform. Since 2012, the Ministry of Education issued the "Education Informatization Ten years Development Plan", the informatization reform of education in China has a clear theoretical and policy support to change the traditional teaching concept and teaching model. The innovation of teaching idea and teaching means laid the foundation. College English course is an important public basic course in colleges and universities. To some extent, the quality of this course affects the effect of other subjects and majors. Improving the quality of college English teaching can help students to learn professional knowledge better, broaden the international perspective, and improve the competitiveness of employment. At present, the most common teaching method in college English teaching is the traditional teaching mode and teaching method. The effect of classroom teaching is not obvious[1]. Flipping classroom is a kind of teaching mode which is different from the traditional teaching in concept and method. It has been actively applied and popularized by many colleges and universities in the United States, but it is still in its infancy in China, so we should actively introduce the flipping classroom model and apply it to the practice of college English teaching in the new era. With the help of the advantages of information development, college English teaching is reformed and innovated in order to improve the level of college English teaching and improve the students' English application ability.

\section{The Definition, Development and Teaching Process of The Flipping Classroom}

The Definition of the Flipping Classroom. The Flipping classroom is also called reverse classroom, or reverse classroom, is a new teaching mode, specifically refers to teachers on the basis of teaching objectives and basic teaching content, the integration of new and old knowledge. Combine the important and difficult points in the teaching content into teaching video or other teaching materials, then ask the students to study independently according to these teaching materials before class, and complete the online autonomous test. Then the teachers analyze the problems in the students' autonomous learning test in class, and then organize the students to carry out group discussions. In the joint efforts of teachers and students to solve the important and difficult problems, help students consolidate the old knowledge, but also complete the new knowledge of learning understanding and mastery[2].

The Development of the Flipping Classroom. The basic idea of the flipping class was first put forward by General Sylvanas Seyer at West Point, an innovative teaching model in which students go through preview. Cooperative communication not only inspires divergent thinking and critical 
thinking, but also exercises the ability of communication, cooperation and analysis and problem solving. In early -10s, Harvard physics professor Eric Mazur created the Peer approach, which required students to teach themselves on an off-course basis. In class, interactive activities such as "Question-Reflection-Response" are the main activities, which effectively solve the problem of students' understanding of the knowledge content caused by the teaching-style teaching. At the same time, also officially opened the "flip classroom" prelude. Since then, although the flipping classroom model has been applied in the economics classroom, physics classroom has not formed the concrete concept. Through the practice application of the innovative teaching model and the enrichment of the theoretical connotation. It was not until 2011, when Salman Khan gave a speech on "reconstructing Education with Video" on TED, that the discussion and research on flipping classroom teaching was stimulated. Flipping classroom has also become an important technology that affects the quality of classroom teaching. The educational circles around the world have joined the practice of flipping classroom.

\section{A Feasibility Analysis on the Application of Flipping Classroom in College English Teaching}

Difficulties in College English Teaching. Although college students do not have to be pressured to study college English, most colleges and universities in our country require college students' English ability. For example, non-English majors can only pass CET-4 or CET-4 to get a degree certificate. For example, students who have the need to study abroad and continue their studies must also pass IELTS or TOEFL. From these requirements, it can be found that college English teaching still plays an important role in the future development of students, especially in the language industry. Students working in foreign enterprises must strengthen their English language learning, especially the improvement of listening and speaking skills. Whether they are listening or speaking skills or basic knowledge of reading and writing, college students must master English vocabulary and grammar. Sentence structure, reading comprehension, writing and so on, and can apply these knowledge or skills flexibly. To achieve this teaching goal, it is necessary to build a good language learning environment for students. However, from the current situation of college English teaching, due to the impact of teaching time, teaching site, teaching equipment, teaching content and teacher resources[3]. It is very difficult for the school to create a language environment conducive to improving English learning, so the students' listening, speaking, reading and writing skills are not well trained. Teachers can only use a short time of 45 minutes in class to complete the classroom teaching content to achieve the teaching goals, and students can only be busy recording knowledge points, it is difficult to exercise the ability of listening and speaking opportunities. Even if there are teachers lack of guidance ability, students lack of experience and psychological timidity, shyness and other factors can not effectively complete the skills training. In addition, some college English classes because teachers do not carefully prepare lessons. Combined with the influence of single teaching content and teaching method, the classroom atmosphere is dull, students' interest in learning is weakened, and the knowledge learned can not be effectively applied.

The Advantage of the Flipping Classroom in College English Teaching. The paradigm of "learning first and teaching later" promotes the cultivation of students' autonomous learning ability. The process of learning consists of two parts, one is the transfer of knowledge, the other is the internalization of knowledge. Then realize the internalization of the students' knowledge, that is, the teachers teach the English knowledge in the classroom first, then assign the students' homework after class, so that the students can digest and consolidate what they have learned after the class. Although the teacher has completed the teaching content according to the teaching goal and the teaching plan, but in the knowledge internalization after class, because the teacher has completed the knowledge transfer link. So once students encounter any problems after class they can not get in touch with teachers in time, teachers can not help students solve problems in time, the effect of internalization of students is poor, and after the implementation of the flipped classroom. Knowledge transfer and knowledge internalization are flipped. Before class, the teacher arranges the knowledge into a micro video, and then provides students with independent learning and testing. Then let students to learn the confusion encountered in the classroom teaching under the guidance 
of teachers and teachers and students under the cooperative exchange of learning problems together. This process is more effective than the traditional teaching process. It can effectively help students to complete the consolidation of old knowledge and the integration of new and old knowledge, but also cultivate the students' ability to analyze and solve problems. In addition, under the flipping classroom teaching mode, the microvideo produced by teachers is only about 15 minutes. To meet the attention needs of students, and because the video sets text, pictures and audio and video in one, more rich and vivid, can stimulate students' interest in learning, encourage students to devote themselves to the learning of video resources. In this process can also be suspended, playback, playback and other operations to complete the knowledge learning, to solve the traditional classroom teaching in the single transfer of knowledge, of course, in the flipping classroom mode. Students must carry out autonomous learning, because only through autonomous learning to complete the internalization of new knowledge, in order to interact with other students and teachers in the classroom, so that students want to explore the interest will be stimulated. Be able to better apply English knowledge and skills[4].

The transformation of teachers and students' roles can effectively realize the function of classroom teaching. The traditional teaching mode is limited by the teaching time and the teaching place, the teacher can only use in the classroom to impart the knowledge, the teacher must complete the knowledge transfer process in the limited time and the space. In this process, the most important thing is to explore how to realize the optimization of classroom teaching, but ignore the main position of students. Ignoring the differences and individualized development among students, the function of classroom teaching will not be fully developed, but after the application of flipping the classroom. Students can complete knowledge transfer and knowledge transformation through online learning, and do not need to think too much about maximizing the efficiency of teaching, but focus on the main body of students, students become the center of the teaching process. According to the needs of students and personality characteristics of targeted stratified teaching, so that the classroom function is optimized, can fully realize the value of classroom teaching. The flipping classroom teaching model includes two contents. One is to let students learn independently through micro-video before class, the other is interactive communication in class, in which the cooperative communication between teachers and students is the key to this innovative model. The role between teachers and students has changed, teachers are not only imparting knowledge, but also students' collaborators and mentors, students are no longer passively educated. The teacher is no longer a high authority in classroom teaching, but a real tutor of students, who can help students consolidate the internalization of knowledge in the course of communication and interaction. It can also help students solve phonetic and expressive errors in listening and speaking in time, and students also have more opportunities to exercise listening and speaking skills.

Interactive communication mechanism is formed to cultivate a new type of teacher-student relationship. In the traditional teaching mode, the teacher is the absolute leader, the student is the passive receiver of knowledge, the teacher controls the right to speak, the students' ability of questioning and the ability of innovation are contained. Students' divergent thinking and innovative thinking can not be developed. In the flipping classroom, teachers and students can communicate and interact in both directions, forming a multi-interactive communication mechanism between teachers and students and between students and students. On the one hand, it can narrow the distance between teachers and students, which is conducive to the cultivation of harmonious and equal teacher-student relationship. On the other hand, it is precisely because of the formation of this new relationship, students can be bold innovation, brave doubt. In order to cultivate students' divergent thinking, innovative thinking, logical thinking and independent inquiry, communication and cooperation, analysis and problem-solving ability. In addition, due to the relationship between teachers and students become equal and close. English teachers are not only teachers of students' study, but also become friends of students' lives, so that when students encounter learning and life difficulties, they are more willing to share with teachers, and teachers can give feedback in time. Avoid students' mental problems and improve students' ability to resist stress.

It is beneficial to the realization of educational fairness and the rational allocation of educational 
resources. Influenced by national and regional economic development and other factors, different colleges and universities have different English learning resources, some of which are very limited. Students can not effectively complete the learning and application of English knowledge. After the implementation of the flipping classroom, teachers' teaching is no longer confined to English teaching materials, but can actively integrate English learning resources from different regions and countries. Then make micro video to allow students to learn on their own, so that students from different schools can get the same English learning materials, make up for the lack of learning resources, teachers quality is not enough. Differences in teaching methods and levels lead to poor teaching results, thus contributing to the realization of equity in education. In addition, the integration and utilization of teaching resources in different regions and countries by flipping the classroom. It also promotes the rational allocation of educational resources.

\section{The Specific Application Strategies of Flipping Classroom in College English Teaching}

Clear the Role of the Teacher. After the application of flipping classroom in college English teaching, it will inevitably bring great challenges to teachers' teaching, especially to the authority of teachers, teaching process and teaching methods. Therefore, teachers should first correct their mentality. We should change the traditional educational concept and realize that middle school students are the main body of classroom learning in English teaching, and they are only as mentors and collaborators to eliminate the psychological hierarchical concept. With students to complete the process of learning and application of English knowledge. The teacher's position and role must be clear, otherwise it will affect the effect of the implementation of the flip classroom. In teaching, teachers should fully understand the characteristics and learning needs of students, choose the appropriate teaching content according to the characteristics and needs, and then launch targeted and stratified teaching to change the past popular teaching methods. To improve the quality of English teaching and promote the development of students' individuation[5].

Improving the Information Technology Literacy of Teachers and Students. In the age of information technology, the teaching classroom has gradually changed from the traditional classroom to the information classroom. Therefore, in order to effectively use the flipped classroom in college English teaching, teachers and students' information technology literacy must be improved. Improve the ability of computer application. For teachers, we should master teaching resources collection, integration and micro-video courseware making and dissemination, through the continuous strengthening of computer information technology practice. So that teachers can make full use of information resources, the integration of resources into 15-20 minutes of short video. In the classroom through skilled operation of multimedia equipment to play audio and video, teaching practice activities. Promote the quality of teaching. In addition, for students, students must use computers to complete autonomous learning and testing, after the end of learning, but also to continue to explore the problems found in the computer. In the information age, the ability of information technology of teachers and students should not be an obstacle to the effective application of flipping classroom[6].

Improving Students' Ability to Learn Independently. In the flipping classroom mode, students must independently complete video learning and online testing before class, which puts forward higher requirements for students' self-control and autonomous learning ability. Students should arrange their own time reasonably. Learn and test the online video efficiently before class, then mark the problem that you don't understand. In class, students should be actively integrated into the group communication, used to express their views, promote the solution of the problem; After class, we should continue to explore the knowledge learned independently, so as to better complete the integration of new and old knowledge. The cultivation of students' autonomous learning ability can improve the quality of students and help students to form good study habits. The full implementation of the flipping classroom has a great effect. 


\section{Conclusion}

In summary, flipping classroom is a new teaching mode in the information technology era, which conforms to the trend of educational reform and development, and the application of flipping classroom in college English teaching. It is helpful to make up for the defects in the traditional classroom teaching mode, make students fully play their subjective initiative, and find their own shortcomings through autonomous learning. Then improve the quality of learning and cultivate innovative thinking and comprehensive ability through the improvement of their own literacy and the interaction of classroom communication.

\section{References}

[1] ZHANG Tian. Flipping Classroom and Its Application in College English Teaching[J]. Yangtze River Series,2017(35).

[2] LU Haiyan. The Feasibility Analysis of the Application of "Flipping Classroom" Model based on Microcourse in College English Teaching[J]. Technology Enhanced Foreign Language Education,2014(04).

[3] WU Zhongliang, Zhao Lei. A Probe into the Flipping Classroom Teaching Model based on Network Learning Space[J]. China Educational Technology,2014(04).

[4] MA Zhifang. The Application of Microcourse in College English classroom Teaching[J]. English Square,2017(12).

[5] ZHANG Xinming, HE Wentao. Turn-over Classroom Based on QQ Group and Tablet PC[J]. e-Education Research,2013(08).

[6] ZHANG Jinlei, WANG Ying. Research on the Teaching Mode of Flipping Classroom[J]. Journal of Distance Education,2012(04). 